\title{
Nuclear ROK and US' Military Retrenchment: Changes of Approach toward Korean Peninsula Crisis
}

\author{
Dzulfikar Fathur Rahman \\ Universitas Diponegoro
}

\begin{abstract}
North Korea has conducted sixth nuclear device tests by 2017. But the United States and South Korea persist on their current approach, that is pressure and sanction. The ways in which the United States and South Korea manage the Korean Peninsula crisis beg us to rethink, since the objective thereof, namely denuclearization, has not come into fruition. There are three problems to discuss. First, why North Korea keeps developing its nuclear weapons program. Second, why the current approach of the United States and South Korea seemingly fails. Third, what kind of changes the United States and South Korea need to have. This article argues, South Korea needs to acquire and develop its own nuclear weapons, and the United States needs to perform military retrenchment by retracting United States Forces Korea from the Peninsula. To examine the argument, neorealist theory, Waltz's proposition on the further spread of nuclear weapons, and theory of military retrenchment, all provide necessary framework.
\end{abstract}

Keywords: Korean Peninsula crisis; nuclear ROK; US' military retrenchment; and neorealist theory.

\begin{abstract}
Abstrak
Korea Utara sudah melakukan enam uji coba perangkat nuklir per 2017. Tapi Amerika Serikat dan Korea Selatan bersikeras dengan pendekatannya yang sekarang, yaitu tekanan dan sanksi. Cara-cara Amerika dan Korea Selatan mengelola krisis Semenanjung Korea perlu ditinjau kembali, karena objektifnya, yaitu denuklirisasi, belum tercapai. Ada tiga masalah yang perlu dibahas. Pertama, kenapa Korea Utara terus mengembangkan program senjata nuklirnya. Kedua, kenapa pendekatan Amerika Serikat dan Korea Selatan yang sekarang tampaknya gagal. Ketiga, perubahan apa yang dibutuhkan Amerika dan Korea Selatan. Artikel ini berargumen, Korea Selatan perlu memperoleh dan mengembangkan senjata nuklirnya sendiri, dan Amerika Serikat perlu melakukan penghematan militer dengan menarik Pasukan Amerika Serikat Korea dari Semenanjung Korea. Untuk membahas argumennya, teori neorealis, pendapat Waltz tentang persebaran senjata nuklir yang lebih jauh, serta teori penghematan militer, semua menyediakan kerangka yang dibutuhkan.
\end{abstract}

Kata-kata kunci: krisis Semenanjung Korea; nuklir Korea Selatan; penghematan militer AS; dan teori neorealis. 


\section{Introduction}

Korean Peninsula has been witnessing a long-standing crisis in which the Koreans itself are adversary to one another. The crisis is precedented with the Korean War and events that took place during the Cold War. Great powers are also involved in this crisis, including China, Russia, and the United States (US). This article focuses mainly on how US and South Korea (hereinafter the South or ROK) manage the crisis. The two powers have long been pursuing a 'nuclear-free zone' policy for the Peninsula. In other words, North Korea (henceforth the North or DPRK) has been facing pressure from both sides to capitulate its nuclear weapons program. Given the long period of time, it's worth rethinking whether the longstanding policy needs to remain intact.

The objective of US and South Korea's policy is denuclearization. It is increasingly becomes ill-advised and misleading to pursue this objective any further. Pyongyang had shown the willingness to suffer a severe damage to its international standing by being not cooperative with International Atomic Energy Agency (IAEA), withdrawing from the Non-Proliferation Treaty (NPT), pulling out from the Six-Party Talks, and keep conducting another test of nuclear device until recently. There is no solid reason to believe DPRK will abandon its nuclear weapons program. It is the policy which needs to abandon its objective of denuclearization. The imperative, therefore, is to produce prudence between the North and the South which, in turn, creates peace and stability in the Peninsula.

To that end, it is necessary for the United States to perform military retrenchment by retracting its forces from the Peninsula, and South Korea needs to develop its own nuclear weapons program. Some may fear these changes will only create another crisis at strategic level between the nuclear weapons states. Some may argue, the region cannot afford to have nuclear ROK due to fear of second episode of Korean War in which exchange of nuclear strikes take place. In contrast, as Kenneth Waltz (1981) points out, past events and patterns showed the opposite. Consider, say, India and Pakistan or the United States and Soviet Union.

A nuclear ROK argument is not entirely new in the discourse. In fact, in the year of 1970s, South Korea asserted its own nuclear ambition in response to the United States' plan to withdraw USFK. In 1977, then South Korean President Park Chung-hee himself had had directed South Korean scientists to build atomic bombs (Burr, 2017). The advocates of this argument ranges from analysts and scholars to high profile officials. Among others, for example, Rajaram Panda examined the South Korea's nuclear option in a well-written piece (Panda, 2015). Panda's conclusion is for the South Korea to rely on US' nuclear umbrella. He argues, "it would be prudent for South Korea to remain tied to its alliance relationship with the United States and rely on the extended nuclear deterrence" (Panda, 2015: 171). This article argues the opposite, and will examine the reasons further in the last two sections. But first, this article explores the central tenets of neorealist theory to lay the theoretical framework in order to make sense of the argument. 


\section{Structure of International Politics and Its Consequences}

To understand international politics is to examine its system, which consists of a structure and interacting units. It was Waltz who developed a theory with that proposition, that is neorealism. "The idea that international politics can be thought of a system with a precisely defined structure is neorealism's fundamental departure from traditional realism" (Waltz, 1990: 30). Neorealism provides a useful theoretical framework to understand the nature of the structure of international politics. It is entirely different compared to domestic politics. Structure of international politics is defined by three essential elements. This section, however, only focuses on two among them: the ordering principle; and distribution of capabilities.

The ordering principle of international politics is anarchy. What does it mean to have anarchy as the order? Is there an order at all? Waltz explains this problem as follows. "The parts of international-political systems stand in relations of coordination. Formally, each is the equal of all the others. None is entitled to command; none is required to obey. International systems are decentralized and anarchic" (Waltz, 1979: 88). In other words, there is no authority sovereign over the interacting units to govern them. It is the consequence of states' sovereignty. However, states do not design the structure as they desire. As Waltz remarks, "International-political systems, like economic markets, are individualist in origin, spontaneously generated, and unintended" (Waltz, 1979: 91).

Within neorealist theoretical framework, motivation of states (as the units) is radically simplified. Neorealism assumes that states have a fundamental motivation: to survive. Furthermore, international politics operates with self-help principle. States may seek other ends. Still, survival is needed to pave the way for the other ends to be achievable. Accordingly, states' security must be assured primarily by their own. This is why state arms itself for its own security. This also helps us to understand why North Korea develops nuclear weapons program, and why it generates fear in the South. However, state does not necessarily act for itself and itself only. Some states may seek security through groupings or external balancing. It is evident in the case of South Korea and Japan, whose security relies heavily on the United States' nuclear umbrella at strategic and tactical level.

Another important feature of neorealist theory is distribution of capabilities. States differ to one another in terms of their capability to perform similar task. Within the structure, there are states with greater and lesser capabilities. States with greater capabilities are distinguished from the lesser ones; they are the great powers. The number of great powers in a structure constitutes the polarity of the internationalpolitical systems. Consider, for example, the Cold War era in which the United States and Soviet Union are the only great powers in the system. International-political systems of Cold War era therefore was bipolar. Changes in the number of great powers change the structure of a system. Today's system is in a transition toward a multipolar one, with China is increasingly able to combine effectively its economic, political, military, and social assets. (This is why merely in possession of nuclear 
power does not necessarily reward states the status of great power.)

Multipolar system, according to Waltz (Waltz, 1981), is relatively less stable compared to bipolar system. What happens in the periphery may disrupt the central balance. This explains why the Korean Peninsula crisis does not only concern the Koreans and their immediate neighbor; it concerns, among others, the United States, the United Kingdom, France, and Australia. Although lesser states with nuclear weapons do not change the distribution of capabilities within the structure, its consequence causes sufficient disruption to put the central balance at stake. This is why Waltz advocates the spread of nuclear weapons in a bipolar world, and explains the danger of nuclear weapons in a multipolar one at the same time. This article nevertheless seeks to explain why nuclear weapons for South Korea, in this system, is needed.

\section{Why DPRK Wants Nuclear Weapons}

It was in October, 2006, North Korea detonated its first nuclear device test, whose yield was estimated to be less than one kiloton. It was unclear whether the test was successful. The second test took place in May, 2009. Its yield was estimated to exceed two kilotons. In February, 2013, Pyongyang conducted the third nuclear device test. It was estimated that its yield exceeded seven kilotons. The fourth test took place in January, 2016, but its yield didn't show a dramatic progress from the previous test. The state news agency, Korean Central News Agency (KCNA), reported it was a hydrogen bomb test (Kim, 2016). There was a debate whether it was a test of hydrogen bomb or it was just another fission bomb. In September, 2016, the fifth nuclear device test was conducted. Its yield was estimated to be 10 kilotons. The latest nuclear device test took place in September, 2017. It was thermonuclear weapon, and the estimate of its yield was 100 kilotons (five times more destructive compared to the bomb dropped in Hiroshima, 1945, whose yield was about 20 kilotons).

The world has witnessed six tests of North Korea's nuclear weapons. But why North Korea develops nuclear weapons? This section discusses this question by referring to Waltz's propositions in his seminal work on the spread of nuclear weapons.

Waltz argues, "a country without nuclear allies will want nuclear weapons all the more if some of its adversaries have them" (Waltz, 1981). The United States, as North Korea's adversary, is in a possession of nuclear weapon and once stationed them in the Peninsula. For this reason, North Korea decided to withdraw from the NPT and pull out from the Six-Party Talks in 2009 to acquire and continue to develop its own nuclear weapons. Although South Korea is also regarded as adversary, it does not possess nuclear weapons; nor it poses equal threat to the North regime as the US does through its extended deterrence and military presence in the Peninsula.

Uncertainty of alliance is another reason. Waltz writes, "a state may want nuclear weapons for fear that its great-power ally will not retaliate if the other great 
power attacks" (Waltz, 1981). The case of North Korea is this worse. In this regard, Cold War has far-reaching consequences. The improvement in China-United States relations following the monumental visit by Henry Kissinger in 1971, coupled with the fall of Soviet Union, both had caused Pyongyang's concern. Minor shifts have also been taking place in the year of 2017. This is evident, among others, in the case of the New York diplomatic channel. The United Nations Security Council (UNSC) had unanimously adopted two resolutions which impose sanction on North Korea, namely the resolution 2371 and resolution 2375 (Roth, 2017). Although the unanimous vote is certainly not the first, it implies that China and Russia's approach toward the crisis has been experiencing a shift. Both powers are increasingly becoming ambivalent both toward North Korea and the United States (and its allies). This is why North Korea didn't stop its conduct of nuclear device test in the wake of UNSC's resolutions.

Because of the terror it poses, "some countries may find nuclear weapons a cheaper and safer alternative to running economically ruinous and militarily dangerous conventional arms races. Nuclear weapons may promise increased security and independence at an affordable price" (Waltz, 1981). This is delivered through deterrent strategy. “'To deter' literally means to stop someone from doing something by frightening him. [...] dissuasion by deterrence operates by frightening a state out of attacking, not because of the difficulty of launching an attack and carrying it home, but because the expected reaction of the attacked will result in one's own severe punishment" (Waltz, 1981). In the case of Korean Peninsula crisis, North Korea can deter by, for example, threatening to retaliate or launch a secondstrike nuclear forces. In regard to the idea of alternative to conventional arms races, consider the Terminal High Altitude Area Defense (THAAD) whose agreement for deployment between Seoul and Washington was reached in 2016. North Korea didn't need to immediately deploy the same exact anti-ballistic missile defense system only to balance.

In addition, it is important to understand that the United States presence in itself is a threat to the North. DPRK holds this long-standing hostile position toward the United States since the Korean War broke out in early 1950s. When North Korea began to invade South Korea, the United States intervened. Since then, South Korea relies heavily on the United States' assistance-which created a sort of patron-client relationship. The context of Cold War complicated the hostility between the United States and the North. The state of their relations in the Korean War carries on until present. The United States came in a close proximity as a threat to North Korea. Consider the United States Pacific Command (USPACOM) and its sub-unified command, the United States Forces Korea (USFK). United States' military has been present in the Peninsula for almost six decades.

Presence of the United States as imminent threat consequently generates vigilant behavior from North Korea toward almost every international regime related to nuclear weapons. For example, North Korea once refused to sign an IAEA 
safeguard agreement because the United States' nuclear weapons were stationed in the South (Nye, 1992: 1295). Shortly after then President George H. W. Bush had had announced the United States would remove its nuclear weapons from South Korea in 1991, the North willed to sign the agreement in the following year. Another relevant event to demonstrate the point is when North Korea had accused the United States of invasion prior to the withdrawal from the NPT (Mydans, 2003).

\section{Current Approach of ROK and US Toward the Crisis}

Now that the North has armed itself with nuclear weapons. Response toward this development from the international community is concerted: punish through sanctions, and pressure the regime to capitulate its nuclear weapons program. The international community, especially South Korea and the United States, defies the idea to accustom itself to live with a nuclear DPRK. The objective to create a nuclearfree zone in the Peninsula remains intact. Denuclearization thus means an attempt to reverse the status quo. Although transition of powers took place in South Korea and the United States in the last two years, their approach to the crisis seems to be similar and does not show a significant change from the previous ones. This section discusses the approach of South Korea under President Moon Jae-in, and the United States under President Donald Trump, to manage the nuclear crisis in the Peninsula, and examine why it seemingly fails.

\section{South Korea's Approach}

For the last two administrations, those of then President Park Geun-hye from 2013 to 2017 and President Moon Jae-in, South Korea has been consistent in maintaining its foreign policy in regard to North Korea, that is to pursue reunification and a nuclear-free zone Korean Peninsula. However, transition of power in 2013 was not the first time in history that South Korea's President aspired to work for reunification with the North. In fact, on July 4, 1972, Seoul and Pyongyang announced that there had been agreements in regard to reunification. Moreover, five years before North Korea withdrew from the NPT regime, then President Kim Dae-jung introduced a policy dubbed as the Sunshine Policy. This policy was meant to promote peaceful engagement with Pyongyang by, for example, helping to improve North Korea's economy. Today's President Moon is seemingly continuing his predecessors' policy in large part. To understand his policy and the continuity better, it is necessary to overview the policy of then President Park first.

Before she assumed office, Park had had dropped a hint on her foreign policy toward North Korea. It was her Foreign Affairs article in 2011 which revealed her view of the crisis and her objective. She envisioned a 'new kind of Korea', that is a democratic, unified Korea that could be achieved through trust building (the so-called trustpolitik policy) and alignment policy. In addition, Park reaffirms that "South Korea adheres to denuclearization, [and] participates in countering the proliferation of other weapons of mass destruction [...]" (Geun-hye, 2011:18). 
After Park was elected President, she persisted on that stance. In her inauguration speech in 2013, Park remarked, "Through a trust-building process on the Korean Peninsula I intend to lay the groundwork for an era of harmonious unification where all Koreans can lead more prosperous and freer lives and where their dreams can come true" (Yonhap News Agency, 2013). To realize this vision, Park laid out her strategy which is delivered through, among many, reunion of the separated families throughout the Koreas. This reunion, Park believed, could form a framework to begin a new conversation with Pyongyang (Ji-eun, 2014). To assert her commitment further, Park established Unification Preparatory Committee, whose mandate was to prepare for reunification.

South Korea's Moon Jae-in does not employ an entirely different, new foreign policy toward North Korea. South Korea still aspires to reunification and denuclearization. President Moon has laid out his government's strategy to work for these objectives in his speech at Körber Foundation's event in Berlin, Germany, in early July, 2017. There are two points to note from that speech. First is his policy direction, which encompasses: (1) peace; (2) denuclearization of the Korean Peninsula; (3) a permanent peace regime, by which he meant to institutionalize peace through a peace treaty; (4) new economic map on the Korean Peninsula, which will reconnect the inter-Korean railway, and implement a gas pipeline project; and (5) "nonpolitical exchange and cooperation projects by separating it from the political and military situation," of which President Moon proposed, among others, to allow reunion of families to take place, as well as exchange of the private sector (Hyunjung, 2017).

The second thing the speech unveiled is President Moon's strategy to pursue those policy directions. His speech nicely delivered the step-by-step process of reunification. There are four primary important points (sHyun-jung, 2017). First, to "start with what is easy," as President Moon said, his government suggested that the process can begin by addressing the humanitarian issue. He encouraged the North to agree on the plan for the reunion of families to fall on the day of the October 4 Declaration's anniversary alongside the Koreas' traditional Chuseok holiday. Second, President Moon considered the importance of a series of three Olympics which will be respectively held in Pyeonchang, Korea, in 2018; in Tokyo, Japan, in 2020; and in Beijing, China, in 2022. He suggested North Korea to use these opportunities to build peace between the Koreas. Third, President Moon aimed at a mutual halt of hostile acts around the Military Demarcation Line (MDL), which was expected to be able to prevent further escalation of the conflict. Finally, President Moon reaffirmed that the inter-Korean dialogue is necessary to establish contact between the authorities of Seoul and Pyongyang. More importantly, he expressed his openness and willingness to meet his North Korean counterpart, Chairman Kim Jong-un. For the most part, the conciliatory tone of his policy makes it similar to the Sunshine Policy that it is dubbed by some as 'Sunshine Policy 2.0'. 


\section{The United States' Approach}

It is obvious that the United States persists on its long-standing stance toward the Korean Peninsula crisis, namely denuclearization. In contrast to South Korea's Blue House, United States' White House does not necessarily carry on the policy from previous administration. The assertive manner of the United States' approach toward the North Korean regime remains closely persistent since the Cold War era. More importantly, among others, the US strategy of extended deterrence transcends the transition of power. The United States' nuclear weapons remains important at the strategic level to guarantee security needed by its allies, especially ROK. Notwithstanding the absence of continuity, it remains necessary to understand how then President Barack Obama managed the crisis during his days in office.

Put in a broader context, the 'pivot to Asia' was Obama's foreign policy to engage with the region more deeply. In a more particular context to the Korean Peninsula crisis, his foreign policy was the 'strategic patience'. The policy "primarily indicated that the United States would not move first until North Korea displays a sincere effort to denuclearize and come back to the negotiation table [italics added]" (Kim, 2016: 33). This policy attempted to put pressure on Pyongyang that it would return to the Six-Party Talks, as well as engaged China in a persuasive manner to take tougher stance to punish the North. The US under Obama also pressured the North through espionage (see Goldman, 2017). The New York Channel was, of course, utilized to serve the policy objective, and the US successfully pursued a more robust enforcement of UN sanctions (Martin, 2010: 187). More importantly, the Obama administration acknowledged how important it was to restraint. This particular behavior arguably had kept the United States from a war with the North.

Today's US President is increasingly assertive toward the Korean Peninsula crisis, which tops his agenda in the region. To replace his predecessor's legacy, President Trump introduced a policy of 'strategic accountability. The policy, however, does not abandon the previous strategies embedded in 'strategic patience' altogether. In fact, "It has continued to apply pressure from the Obama playbook, adding only secondary sanctions on several Chinese banks and individuals. Like its forerunner, it places pre-condition on nuclear negotiations with Pyongyang that the regime has less and less interest in meeting" (Connelly, 2017: 14). The pre-condition is where the problem lies. The administration is in want of a completely denuclearized North Korea first only to get Pyongyang and Washington sit for negotiation around the table.

During his early days in office, President Trump showed quite a reverse of the previous policy to restraint. In April of 2017, President Trump announced that the USS Carl Vinson headed a carrier strike group on a journey to the Korean Peninsula. It was believed by some that the presence of the Vinson was intended to shoot down, if any, ballistic missiles fired by the North (Westcott, 2017). The Vinson's position at the time being, however, seemed to be not in line with the rhetoric of President Trump. Notwithstanding the miscommunication between the 
White House and Pentagon in the Vinson case, it is increasingly clear that President Trump is not hesitant to resort to military options as a response toward North Korea's provocation and threat.

What is also a striking difference with the previous US President is Trump's use of Twitter. It is not a rare occasion to see the President reacts to a particular event by publicly expressing it on his Twitter account. His rhetoric on Twitter is as aggressive as his counterpart's on another traditional medium, say state news agency. The latest of which that had escalated tension was his response to North Korean Foreign Minister Ri Yong-ho's statement at the United Nations in September, 2017. President Trump tweeted, "Just heard Foreign Minister of North Korea speak at U.N. If he echoes thoughts of Little Rocket Man [the Chairman Kim, he referred], they won't be around much longer!" (Watson, 2017). His tweets are beyond doubts if it represents the United States' policy and official position. However, at the very least, it is influential insofar as to add more tension to the crisis.

President Trump does not necessarily translate his rhetoric which denounced China during the presidential campaign in 2016. In fact, it seems the US President has been learning how important China is in the region for burden-sharing in the Korean Peninsula crisis. The improvement of US-China relations resurfaced after the state visit by both President Xi Jinping to the United States in April, 2017, and President Trump to the People's Republic in November, 2017. The November visit by President Trump concluded that China and US agreed to fully implement the UNSC resolution, which includes more sanctions, toward the North that it will expectedly capitulate its nuclear weapons program (White House, 2017). President Trump's approach, by far, has done more harm, than good, to the crisis. This was evident in the case of his first speech at UN General Assembly in September, 2017. Chairman Kim responded with yet another aggressive rhetoric with a metaphor. He remarked, referring to Trump, "A frightened dog barks louder" (Guardian Staff, 2017).

\section{Why the Approach Seemingly Fails}

The year of 2017 witnessed North Korea's sixth nuclear device test amidst the pressure and sanction. This case, including the previous tests, clearly shows that the failure of the current ROK and US' approach is evident. Contrary to popular belief, pressure and sanction only double down the North's ambition to keep its nuclear weapons program. To examine this puzzle, it is important to bear in mind the central tenets of neorealism. There are several reasons why this current approach is yet to bring about success.

In a world whose ordering principle is anarchy, North Korea's first and foremost motivation is survival. Power serves as means to ensure the North Korea's survival. Power primarily consists of, but not limited to, economic and military capabilities. For the latter, nuclear weapons definitely serves the function thereof. As what has been explained in the previous section, self-help principle applies in this 
anarchic international-political system. North Korea's nuclear weapons program thus is a way to provide security for itself and on its own. All this endures the North's survival. As a consequence, it is only natural if the North refuses to give up its nuclear weapons program in the face of a pressure and sanction from its adversaries. Even pressure and sanction in itself are threat to the survival of the North-let alone the driving force of them. Besides, to paraphrase Waltz (1981), none is entitled to command; North Korea, therefore, is not required to obey.

Distribution of capabilities tells us something about relative capabilities and how states manage to respond the asymmetry. The United States, having successfully combined its economic, political, social, and military assets, is one of the great powers in the system. North Korea, on the contrary, is the lesser party. South Korea is arguably the calibre of DPRK. The problem lies in the relative capabilities. Faced with threat from US-led alliance's capabilities, the North is relatively weaker in terms of power. This is why the North is not willing to capitulate its nuclear weapons. It serves the deterrent strategy. This strategy transcends beyond the relative capabilities of which the North greatly suffers. As Charles de Gaulle would say, "nuclear weapons make alliances obsolete," and Waltz remarks, "At the strategic level he was right" (Waltz, 1981). If, and only if, the South is left alone, the relative capabilities between the two should not be a problem for the North.

The Korean Peninsula crisis overlaps with the transition of internationalpolitical system from bipolar to a multipolar one. The consequences are farreaching. The most important, among many, is the growing uncertainty of who is a danger to whom. Waltz writes, "With three or more powers, flexibility of alliances keeps relations of friendship and enmity fluid and makes everyone's estimate of the present and future relation of forces uncertain" (Waltz, 1981). In international politics, friendship and enmity are transient qualities. This is why there is change in China's policy toward the crisis; change in the United States' position toward China's policy in regard to North Korea; and so forth. Accordingly, to capitulate its nuclear weapons is to put North Korea in a worse condition, in which the uncertainty resurfaces. South Korea's friendly behavior at the present does not guarantee a growing friendship with the North in the long-run.

The growing uncertainty may account for how states choose to balance the threat they face. States balance internally as the primary strategy in response to the threat they face. It means the states rely heavily on their own assets and resources to provide security rather than depend greatly on alliance. In line with this, DPRK balances internally against the perceived threat from ROK and US by developing its own nuclear weapons. The minor changes in China's policy, be that as it may, add to the growing uncertainty. How China changes in rhetoric is demonstrated by, among others, its call on the North, shortly after the sixth nuclear test, "to stop taking wrong actions that exacerbate the situation and are not in its own interest" (cited in Albert, 2017). More importantly, President Xi's visit to Seoul in 2014, in which he met with then South Korean President Park, while Chairman Kim had 
never been invited to Beijing, exacerbated the relations between these three powers (see Panda, 2015:170). Although it's quite obvious that China will not let a regime change that's forced by external power, it does not negate the uncertainty. Besides, given their complex relations, China cannot offer a helping hand at the expense of its relations with the United States and South Korea.

All this sheds light on why pressure, provocation, military threat, and sanction do not bring the objective of denuclearization closer. In fact, it keeps the effort from reaching it. Not only the approach is problematic, but also the objective is misleading. As a consequence, an approach of this kind begs rethinking: whether or not to persist on this trajectory. This is the very reason why South Korea and the United States need to change course. The next two sections further this argument.

\section{A Nuclear ROK}

An option to go nuclear dates back to the administration of Park Chung-hee in the 1970s, when he first introduced the intention. Then President Park, however, chose to turn down the ambition before it was translated into South Korea's nuclear arsenal. Had Park persisted, the debate would not endure. In 2013, another call for South Korea to go nuclear was echoed by Chung Mong-joon, then member of ROK's National Assembly from Saenuri Party. Chung invited South Koreans to "think the unthinkable," that is to reconsider the nuclear option to match North Korea's nuclear capability (Panda, 2015: 156). This section examines why this option is necessary, and sufficient, to bring about peace and stability in the Korean Peninsula.

To start the discussion, it is important to note South Korea's present nuclear capability. Since it first decided to make use of nuclear power, today's South Korea is in a possession of twenty-four nuclear reactors. $40 \%$ of ROK's electricity is generated by these reactors (Panda, 2015: 168). As of 2016, South Korea was the fifth-largest producer of nuclear energy, followed by Canada (Nuclear Energy Institute, 2016). What is more important about this nuclear capability is how will this potential translate into military use. South Korea's nuclear reactors and its stockpile of spent fuel, according to Charles Ferguson, former president of the Federation of American Scientists, are enough for over 4,300 bombs, and it will only take six months to build its own nuclear weapons (Sanger et al., 2017). Today's potential, so to speak, makes a good starting point.

To bring peace and stability in the Peninsula, contrary to popular belief, South Korea needs to go nuclear because this weapon, as far as history disclosed, can produce prudence in the relations among nuclear weapons state, albeit they may dwell on a hostile situation. There are several reasons to affirm this proposition, to borrow Waltz's unusual conclusion on the further spread of nuclear weapons (Waltz, 1981).

First, think again of the self-help principle in international politics, in which the ordering principle is anarchy. North Korea develops its own nuclear weapons program to provide itself for its own security which, eventually, ensures its survival. 
Likewise, South Korea needs to acquire nuclear weapons to provide security for itself on its own. Some government officials have had voiced this concern. Consider, for example, the call from Won Yu-cheol, member of the National Assembly from Saenuri Party, in 2016. Won remarked with a metaphor, "We cannot borrow an umbrella from a neighbor whenever it rains [...]. We must be prepared and wear our own raincoat" (Myo-ja, 2016). South Korea may have a military posture ready to respond an accidental strike from the North, however, this balance is limited to the tactical level. South Korea needs to balance against the North by primarily relying on its own assets.

Second, nuclear weapons between Seoul and Pyongyang generate a condition in which balance of terror is prominent. Waltz's remark demonstrates it as follows, "the impossibility of one side destroying enough of the other side's missiles to make a retaliatory strike bearable, [consequently makes] the balance of terror is indestructible" (Waltz, 1981). To demonstrate this point, and to paraphrase Waltz (1981), would North Korea try to destroy South Korea's nuclear weapons at the risk of several bombs surviving to fall on Pyongyang and Hamhung? And what would be left of South Korea if Seoul and Busan were destroyed? All this makes preventive or pre-emptive strike less likely.

Third, wars are mainly product of miscalculation, and nuclear weapons make states behave with cautions toward one another. Nuclear weapons, and its possible damage, will force North Korea and South Korea to behave cautiously in responding to their conduct respectively. As consequence, nuclear weapons render miscalculation difficult, if not impossible, because it is important to be aware of the possible damage thereof. Even the United States' response to the aggressive behavior of DPRK is cautious and wary.

Fourth, nuclear weapons serve the deterrent strategy. "It nevertheless remains true that the incidence of wars decreases," Waltz argues, "as the perceived difficulty of winning them increases. No one attacks a defence believed to impregnable" (Waltz, 1981). In this case, uncertainty of damage deters. South Korea's second-strike capability can deter North Korea that it fears the South may impose severe damage (as retaliation) later if it decides to strike first. Deterrence works, to paraphrase Waltz (1981), because nuclear weapons enable South Korea to punish North Korea severely without first defeating it and vice versa. The expected cost of war therefore raises that war becomes less likely.

All this makes an option for nuclear ROK is more sensible and useful to achieve peace and stability in the region. To get a sense of this argument, consider the relations between nuclear weapons states in the Cold War era: the United States and Soviet Union; China and Soviet Union; Israel and Libya; as well as India and Pakistan. Although North Korea-South Korea are the lesser states in the internationalpolitical system and not in the calibre of US-Soviet Union, the replicability remains. Not only it produces prudence, nuclear weapons render conventional arms races between Seoul and Pyongyang unnecessary. 


\section{US’ Military Retrenchment}

The USFK has been experiencing many changes in its number of soldiers since 1950s. It is arguably clear the subordinate command has faced a considerable amount of decline, from approximately 300,000 to roughly 30,000 . This significant reduction, however, does not make the United States a declining power. Be that as it may, there are several reasons why US needs to perform military retrenchment in the Peninsula. Kyle Haynes develops a theory of military retrenchment in relative decline may shed light on this discussion. Although today's US, arguably, does not fit the decline that model posits, this theory is useful in part to explain military retrenchment itself and in what condition retrenchment is sensible.

Haynes defines military retrenchment as "the systematic, voluntary reduction or withdrawal of international defense commitments, troop deployments, and military bases through which a state upholds order abroad" (Haynes, 2015: 491). Put in the context of Korean Peninsula crisis, the United States can completely withdraw the USFK and, perhaps, redeploy this forces elsewhere. This withdrawal is necessary because USFK constitutes a presence of which poses an imminent threat to North Korea. The continuity of US' presence in the Peninsula is not absolutely productive. It adds to the cause of instability in the Peninsula. If withdrawal of this sub-unified command takes place, the US may break away from its long-standing spiral of hostility with the North. This withdrawal entails a necessary and sufficient pre-condition so that the US' interest in the Peninsula stays.

Before a state retrenches, it costs an assurance whether its interest in the region can endure, or its desire to see the existing order stays. In consequence, a state's retrenchment depends in large part on the availability of its successor. For a retrenchment to be optimal, as Haynes argues, there needs to be a suitable successor (Haynes, 2015: 492). To that end, the United States needs to provide assistance and help South Korea acquire and maintain its nuclear weapons. It happened in the case of Britain and France; it can happen in the case of South Korea. As far as ROK-US relations has been developing, there is no reason to doubt the general replicability in large part. To devolve this responsibility to South Korea does not constitute a disengagement. It is, in fact, a means to balance externally against the North through alliance, which extends to Japan.

USFK is not necessary, for the United States can rely heavily on its own nuclear weapons. Again, deterrence serves the purpose thereof. Operational and tactical forces' presence in the immediate neighbor of DPRK poses traditional threat which, in turn, contributes to instability and hostile behavior from DPRK. All this renders USFK to be counterproductive in bringing about stability in the Peninsula. Deterrent strategy does not necessarily require presence of such forces. Moreover, the United States has its forces deployed in Japan, the United States Forces Japan (USFJ). To demonstrate this point further, take the October Crisis which resulted in withdrawal of Soviet Union's nuclear weapons from Cuba. The deterrent strategy of Soviet Union's nuclear weapons could still work after all. But for the United States' 
extended deterrence to work optimally, it needs to show its vital interest in South Korea. Retrenchment does not mean absence of interest altogether. In fact, ROK-US relations is complex. Their economic relations may account for this, for example the United States-Korea Free Trade Agreement (KORUS FTA).

A nuclear ROK alone shall suffice to deter North Korea which later generate peace and stability in the Peninsula. Consequently, it reduces South Korea's dependency on the United States. Waltz puts it this way, "Nuclear weapons increase the ability of states to fend for themselves when the integrity of their legitimate boundaries is at stake. [...] Independent nuclear forces reduce dependency by lesser powers on others without eliminating it" (Waltz, 1981). Although South Korea's dependency on US remains for the small part, South Korea's nuclear weapons relieve a considerable amount of US' burden. Again, this burden-sharing constitutes US' external balancing.

One may argue for the United States to extend its presence to the periphery in this transitional period to a multipolar system. Retrenchment of USFK does not remove US' presence from the Peninsula completely. International politics does not take place merely at the tactical level. The United States' engagement through the Six-Party Talks, UNSC, and USPACOM in general, all of which extends US' reach to the periphery. Relations of South Korea with the United States is not solely based on the USFK's presence in the Peninsula. To paraphrase Waltz (1981), the United States' relations with South Korea is based on complex historical, economic, political, and military considerations, and they are not likely to change much albeit the South decides to build nuclear forces. Seoul therefore may not-and probably will not-completely detach the Peninsula from the United States' reach.

\section{Conclusion}

Spread of nuclear weapons serves the objective to create peace and stability. The United States and Soviet Union as well as India and Pakistan didn't fight a major war because of nuclear weapons. South Korea and North Korea are likely to conform with the pattern. In addition, US' military retrenchment is necessary for stability to prevail in the Peninsula, because its presence is counterproductive. Implication of this argument concerns the rest of the Asia-Pacific region in two respects.

Firstly, one may wonder about the relations between nuclear ROK and the other states in the region. The answer is they may not experience change. Relations of South Korea with the other states, even with China, are complex in the manner. There are other interests that outweigh the issue, say, to isolate South Korea from international trade that it prevents the South from further proliferation. Pre- and post-nuclear relations of the United States with other states unfolded in such ways (Waltz, 1981). South Korea's involvement in East Asia Summit (EAS) is one of the evidences that member states of Association of Southeast Asian Nations (ASEAN) are in possession of such interests, say economic partnership. ASEAN states may not want to denounce ROK because of the nuclear weapons at the expense of other more important interests. 
Secondly, when a new nuclear weapons state emerges, possibility of 'nuclear domino effect' opens, especially in the region. That being said, one may concern the further spread of nuclear weapons to, say, Japan or extensively to the Southeast Asian states. The causality, however, depends in large part to the transient qualities between South Korea and the relevant states. Put in the context of Korean Peninsula crisis, hostility between the Koreas is prominent that it is sensible and urgent to acquire nuclear weapons. Japan, Vietnam or Indonesia, for example, are not in equal position with the Koreas. Other than the North, states in the Asia-Pacific region do not face enmity with South Korea. Thus, although the transitional period toward multipolar system may expose them to instability and uncertainty, status quo of the relations among states may endure in the short-run. In a more extreme case, where there is no enmity at all, there's a reason to depict a situation in which the domino does not fall.

\section{References}

Albert, E. (2017). The China-North Korea Relationship [online], Council on Foreign Relations. Tersedia dalam <https://www.cfr.org/backgrounder/china-northkorea-relationship > [Diakses 12 November 2017].

Burr, W. (2017). Stopping Korea from Going Nuclear, Part I [online], The National Security Archive. Tersedia dalam <https://nsarchive2.gwu.edu/nukevault/ ebb582-The-U.S.-and-the-South-Korean-Nuclear-Program,-1974-1976,Part-1/> [Diakses 5 November 2017].

Connelly, A. L. (2017). Autopilot: East Asia Policy under Trump. Lowy Institute Analyses, October 2017.

Geun-hye, P. (2011). A New Kind of Korea: Building Trust Between Seoul and Pyongyang. Foreign Affairs, 90 (5), pp. 13-18.

Guardian staff. (2017). 'A rogue' and a 'dotard': Kim Jong-un's statement on Trump in full [online], The Guardian. Tersedia dalam <https://www.theguardian. com/world/2017/sep/22/a-rogue-and-a-gangster-kim-jong-uns-statementon-trump-in-full> [Diakses 12 October 2017].

Goldman, R. (2017). How Trump's Predecessors Dealt With the North Korean Threat [online], The New York Times. Tersedia dalam <https://www.nytimes. com/2017/08/17/world/asia/trump-north-korea-threat.html> [Diakses 12 November 2017].

Haynes, K. (2015). Decline and Devolution: The Sources of Strategic Military Retrenchment. International Studies Quarterly, 59, pp. 490-502.

Hyun-jung, B. (2017). Full text of Moon's speech at the Korber Foundation [online], The Korea Herald. Tersedia dalam <http://www.koreaherald.com/view. php?ud=20170707000032> [Diakses 12 November 2017].

Ji-eun, S. (2014). Unification may be jackpot: Park [online], Korea JoongAng Daily. Tersedia dalam <http://koreajoongangdaily.joins.com/news/article/article. aspx?aid=2983129> [Diakses 12 November 20117]. 
Kim, J. (2016). North Korea's Kim Jong Un says H-bomb test self-defensive step against the U.S. [online], Reuters. Tersedia dalam <https://www.reuters.com/ article/us-northkorea-nuclear/north-koreas-kim-jong-un-says-h-bombtest-self-defensive-step-against-the-u-s-idUSKCN0UN0Y420160109> [Diakses 9 November 2017].

Martin, C. H. (2010). Barack Obama and North Korea: A Study in Presidential Transition. Pacific Focus, XXV (2), pp. 181-210.

Mydans, S. (2003). North Korea Assailed for Withdrawing From Arms Treaty [online], The New York Times. Tersedia dalam <http://www.nytimes. com/2003/01/10/international/north-korea-assailed-for-withdrawingfrom-arms-treaty.html $>$ [Diakses 6 October 2017].

Myo-ja, S. (2016). Saenuri's floor leader calls for a nuclear South [online], Korea JoongAng Daily. Tersedia dalam <http://koreajoongangdaily.joins.com/ news/article/article.aspx?aid=3015115> [Diakses 13 November 2017].

Nuclear Energy Institute. (2016). Top 10 Nuclear Generating Countries [online], Nuclear Energy Institute. Tersedia dalam <https://www.nei.org/KnowledgeCenter/Nuclear-Statistics/World-Statistics/Top-10-Nuclear-GeneratingCountries\#> [Diakses 12 November 2017].

Nye, Jr, J. S. (1992). New Approaches to Nuclear Proliferation Policy. Science, 256 (5061), pp. 1293-1297).

Panda, R. (2015). Should South Korea Go Nuclear? Asia-Pacific Review, 22 (1), pp. $148-176$.

Roth, R. (2017). UN Security Council imposes new sanctions on North Korea [online], CNN. Tersedia dalam <http://edition.cnn.com/2017/08/05/asia/ north-korea-un-sanctions/index.html> [Diakses 6 October 2017].

Sanger, D. et al. (2017). North Korea Rouses Neighbors to Reconsider Nuclear Weapons [online], The New York Times. Tersedia dalam <https://mobile. nytimes.com/2017/10/28/world/asia/north-korea-nuclear-weapons-japansouth-korea.html? referer=https://t.co/rODa2usEt0?amp=1> [Diakses 3 November 2017].

Waltz, K. (1979). Theory of International Politics. Massachusetts: Addison-Wesley Publishing Company, Inc.

Waltz, K. (1981). The Spread of Nuclear Weapons: More May Be Better. London: The International Institute for Strategic Studies.

Waltz, K. (1990). Realist Thought and Neorealist Theory. Journal of International Affairs, 44 (1), pp. 21-37.

Watson, C. (2017). Twitter says Trump's threat to North Korea was 'newsworthy' and will not be taken down [online], The Guardian. Tersedia dalam $<$ https:// www.theguardian.com/technology/2017/sep/26/twitter-trump-threatnorth-korea-newsworthy $>$ [Diakses 12 November 2017].

Westcott, B. (2017). Where in the world is the USS Carl Vinson? [online], CNN. Tersedia dalam <http://edition.cnn.com/2017/04/19/asia/uss-carl-vinson- 
north-korea-timeline/index.html> [Diakses 12 November 2017].

White House. (2017). President Donald J. Trump's Visit to China [online], White House. Tersedia dalam <https://www.whitehouse.gov/the-pressoffice/2017/11/10/president-donald-j-trumps-visit-china> [Diakses 12 November 2017].

Yonhap News Agency. (2013). Full text of Park's inauguration speech [online], Yonhap News Agency. Tersedia dalam <http://english.yonhapnews.co.kr/ national/2013/02/25/95/0301000000AEN20130225001500315F.HTML> [Diakses 11 November 2017]. 